\title{
Combining stable isotopes and skeletal growth marks to detect habitat shifts in juvenile loggerhead sea turtles Caretta caretta
}

\author{
Melissa L. Snover ${ }^{1, *}$, Aleta A. Hohn ${ }^{2}$, Larry B. Crowder ${ }^{1}$, Stephen A. Macko ${ }^{3}$ \\ ${ }^{1}$ Duke University Marine Lab, 135 Duke Marine Lab Road, Beaufort, North Carolina 28516, USA \\ ${ }^{2}$ NOAA, NMFS, SEFSC, 101 Pivers Island Road, Beaufort, North Carolina 28516, USA \\ ${ }^{3}$ Department of Environmental Sciences, University of Virginia, 291 McCormick Road, Charlottesville, Virginia 22903, USA
}

\begin{abstract}
Understanding the phase and timing of ontogenetic habitat shifts underlies the study of a species' life history and population dynamics. This information is especially critical to the conservation and management of threatened and endangered species, such as the loggerhead sea turtle Caretta caretta. The early life of loggerheads consists of a terrestrial egg and hatchling stage, a posthatchling and juvenile oceanic, pelagic feeding stage, and a juvenile neritic, primarily benthic feeding stage. In the present study, novel approaches were applied to explore the timing of the loggerhead ontogenetic shift from pelagic to benthic habitats. The most recent years of somatic growth are recorded as annual marks in humerus cross sections. A consistent growth mark pattern in benthic juvenile loggerheads was identified, with narrow growth marks in the interior of the bone transitioning to wider growth marks at the exterior, indicative of a sharp increase in growth rates at the transitional growth mark. This increase in annual growth is hypothesized to correlate with the ontogenetic shift from pelagic to benthic habitats. Stable isotopes of carbon and nitrogen just interior and exterior to the transitional growth mark, as well as stable isotopes from pelagic and benthic flora, fauna and loggerhead stomach contents, were analyzed to determine whether this transition related to a diet shift. The results clearly indicate that a dietary shift from oceanic/pelagic to neritic/benthic feeding corresponds to a transitional growth mark. The combination of stable isotope analysis with skeletochronology can elucidate the ecology of cryptic life history stages during loggerhead ontogeny.
\end{abstract}

KEY WORDS: Sea turtle $\cdot$ Caretta caretta $\cdot$ Growth $\cdot$ Skeletochronology $\cdot$ Stable isotopes

\section{INTRODUCTION}

Loggerhead sea turtles Caretta caretta are highly migratory, with juveniles making transoceanic migrations (Carr 1987, Bolten et al. 1998), and they occupy a variety of different habitats over the course of their lives. Juvenile loggerhead sea turtles undergo at least 1 major ontogenetic habitat shift, viz. the transition from a pelagic to a benthic habitat (Carr 1987). Similar ontogenetic habitat shifts are widespread in other mobile marine species as animals settle from a pelagic, dispersing environment to benthic existences in juvenile nurseries and eventually to adult habitats (e.g. Dahlgren \& Eggleston 2000, Etherington et al. 2003, Snover 2008). These organisms, which span a large range of body sizes during their ontogeny, often alter their habitat and diet as they grow in order to obtain optimal growth rates while minimizing predation mortality (Werner \& Gilliam 1984, Werner 1988, Dahlgren \& Eggleston 2000). Animals may use nutritionally suboptimal habitats to minimize the risk of predation until a minimum size-threshold refuge is attained that coincides with an ontogenetic habitat shift. Because of this, ontogenetic habitat shifts often reflect a growth advantage in the new habitat, as demonstrated for bluegill sunfish Lepomis macrochirus and Nassau grouper Epinephelus striatus (Werner et al. 1983, Werner \& Hall 1988, Dahlgren \& Eggleston 2000).

Skeletochronology is the study of growth marks in the bones of reptiles and amphibians. As with most 
vertebrates, as sea turtles age they deposit growth marks in their bones (Zug et al. 1986, 1995, Klinger \& Musick 1992, 1995, Parham \& Zug 1997, Bjorndal et al. 2003). With few exceptions, distinct growth marks are usually annual and so can be used to age turtles (Klinger \& Musick 1992, Coles et al. 2001, Snover \& Hohn 2004). In addition, the thickness of a growth mark is proportional to growth in carapace size, allowing estimation of individual growth rates (Snover et al. 2007). Based on our observations of humeri from small loggerheads found stranded along the US Atlantic coast, the growth marks in small benthic juvenile loggerheads display a consistent shift in their layering pattern, whereby narrowly spaced growth marks in the interior of the bone transitioned to more widely spaced growth marks at the exterior, indicative of a sharp increase in growth rates at the transitional growth mark. This observed pattern shift in growth lamina led to the hypothesis of the current study, i.e. that there is a growth benefit associated with the offshore/pelagic to nearshore/benthic habitat shift. Similar settlement marks are commonly displayed in the daily growth increments of many tropical marine vertebrates (e.g. Bathygobius coalitus, Shafer 2000).

Because the spatial pattern of the growth marks directly correlates with somatic growth rates, and carapace lengths can be estimated from the diameter of the growth marks (Snover et al. 2007), a similar shift in growth rates should be detectable from the growth mark patterns in humerus cross sections from loggerheads, and this shift should be predictive of the size and timing of recruitment to benthic habitats. The correlation of the shift in layering pattern to the ontogenetic habitat shift was tested in this study using stable isotopes.

Variation in stable isotopes of a single element can provide valuable information on an animal's foraging behavior and habitat use (West et al. 2006). Isotope variations cascade up food webs, with stable isotopes of nitrogen $\left({ }^{15} \mathrm{~N}:{ }^{14} \mathrm{~N}\right.$ or $\left.\delta^{15} \mathrm{~N}\right)$ values fractionating at a faster rate than those of carbon $\left({ }^{13} \mathrm{C}:{ }^{12} \mathrm{C}\right.$ or $\left.\delta^{13} \mathrm{C}\right)$, making it possible to detect changes in trophic-level feeding within the same food web (Minagawa \& Wada 1984, Rau et al. 1992, Michener \& Schell 1994, Kelly 2000). This occurs because the heavier isotopes $\left({ }^{15} \mathrm{~N}\right.$ and ${ }^{13} \mathrm{C}$ ) are conserved and concentrate up food webs, resulting in predictably increasing values as trophic level increases (Rau et al. 1992). Stable isotopes of carbon can be representative of different food webs due to the nature of photosynthesis in the primary producers (West et al. 2006). In general, offshore ecosystems tend to have lower concentrations of ${ }^{13} \mathrm{C}$ than nearshore ecosystems (Michener \& Schell 1994).

Stable isotopes retained in inert structures such as dentin, keratin, and collagen provide records of diet on annual or even daily time scales (Hobson \& Sease 1998, Burton \& Koch 1999, Walker \& Macko 1999, Walker et al. 1999, Cerling et al. 2006, Estrada et al. 2006, West et al. 2006, Knoff et al. 2008, Newsome et al. 2009). Using red blood cells, McClellan et al. (2010) validated that $\delta^{15} \mathrm{~N}$ is significantly greater in red blood cells of benthic loggerhead turtles from the Northwest Atlantic as compared to oceanic turtles in the same population. Hence, stable isotopes of carbon and nitrogen within the bone cross sections can be used to establish whether a shift in diet occurred simultaneously with a growth rate shift at the time of settlement.

In the present study, skeletochronology was combined with stable isotope analysis to detect the timing of an ontogenetic habitat shift in the Northwest Atlantic population of loggerhead sea turtles. The hypothesis tested is that growth rate shifts observed from the spacing of growth marks in cross-sections of benthic loggerhead humeri correspond to a shift in diet and that this shift is consistent with the transition from pelagic to benthic habitats. We tested this hypothesis using the stable isotopes $\delta^{15} \mathrm{~N}$ and $\delta^{13} \mathrm{C}_{i} \delta^{15} \mathrm{~N}$ provides information on trophic position, while $\delta^{13} \mathrm{C}$ provides information on habitat (oceanic/pelagic versus neritic/benthic). In the current study, 'pelagic' is used to refer to the oceanic/pelagic habitat and 'benthic' is used to refer to the neritic habitat where loggerheads primarily feed in the benthos, as these terms identify the primary feeding zones for loggerheads in these habitats.

\section{MATERIALS AND METHODS}

Humerus preparation. Front flippers from dead loggerheads stranded along the coasts of North Carolina, Virginia, and Maryland (USA) between 1997 and 1998 were used in this study. For most of the turtles, straight carapace length (SCL) was recorded, measured as standard straight-line length from the nuchal notch to the posterior end of the posterior marginal. If only curved carapace length (CCL) was recorded, it was converted to SCL using the following regression equation generated from 203 paired measurements from stranding records for loggerheads from 3.8 to $114.7 \mathrm{~cm}$ SCL $\left(\mathrm{r}^{2}=0.966 ; \mathrm{p}<0.001\right)$

$$
\mathrm{SCL}=0.923 \times \mathrm{CCL}+0.189
$$

In the Northwest Atlantic, loggerheads recruit from the pelagic habitat between 42 and $59.5 \mathrm{~cm}$ SCL (Bjorndal et al. 2000). We selected a sample of 23 specimens between 47.7 and $65.8 \mathrm{~cm} \mathrm{SCL}$, as these turtles are likely to have recently recruited to the benthic habitats. Humeri were prepared for skeletochronology following the methods of Snover \& Hohn (2004). A 2 to 
$3 \mathrm{~mm}$ thick cross-section was taken from the proximal end of the bone at the site of the deltopectoral muscle insertion scar. An additional $1 \mathrm{~mm}$ thick cross section was taken adjacent to the sectioning location on each humerus and saved unpreserved for stable isotope ratio analysis. The thicker sections were fixed in $10 \%$ neutral buffered formalin (Fisher Scientific), then decalcified using a commercial decalcifying agent (RDO, Apex Engineering Products). Time to decalcification varied with the size of the bone and the strength of the solution, usually between 24 and 36 h. Following decalcification, $25 \mu \mathrm{m}$ cross-sections were made using a freezing-stage microtome. Sections were stained in Ehrlich's hematoxylin diluted 1:1 with distilled water and mounted on slides in $100 \%$ glycerin.

Growth mark analysis. Thin cross sections of bone display thin, darkly stained lines of arrested growth (LAGs) that alternate with broad lighter stained zones, representing the region of active growth (Castanet et al. 1993). Together, 1 LAG and 1 broad zone make up a skeletal growth mark for 1 yr of growth in loggerhead turtles (Klinger \& Musick 1992, Coles et al. 2001, Snover \& Hohn 2004). In a cross section, the interior LAGs closest to the medulla represent growth earlier in life, while the most external LAG is recently deposited near the external surface of the bone. The growth increment represented by a LAG contains the osseous growth of the year before the LAG was deposited (Fig. 1).

Digital images of the stained sections were taken at $10 \times$ magnification. Image measurements of growth mark diameters on the lateral axis of the bones were made parallel to the dorsal edge. When an outer growth mark diameter was notably larger than the preceding growth mark, the preceding LAG was identified as LAG(0). Thus, for each bone, we numbered the LAGs by designating the one just previous to the increase in the growth mark thickness as LAG(0),

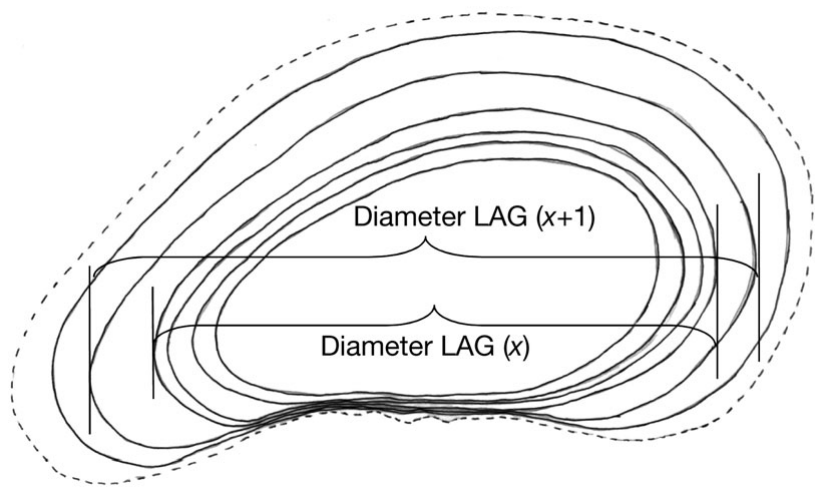

Fig. 1. Caretta caretta. Schematic drawing of a humerus bone cross section. Outer dashed line represents the outside of the bone, solid lines represent lines of arrested growth (LAGs). Growth increment for LAG $(x+1)=$ Diameter LAG $(x+1)-$ Diameter LAG $(x)$

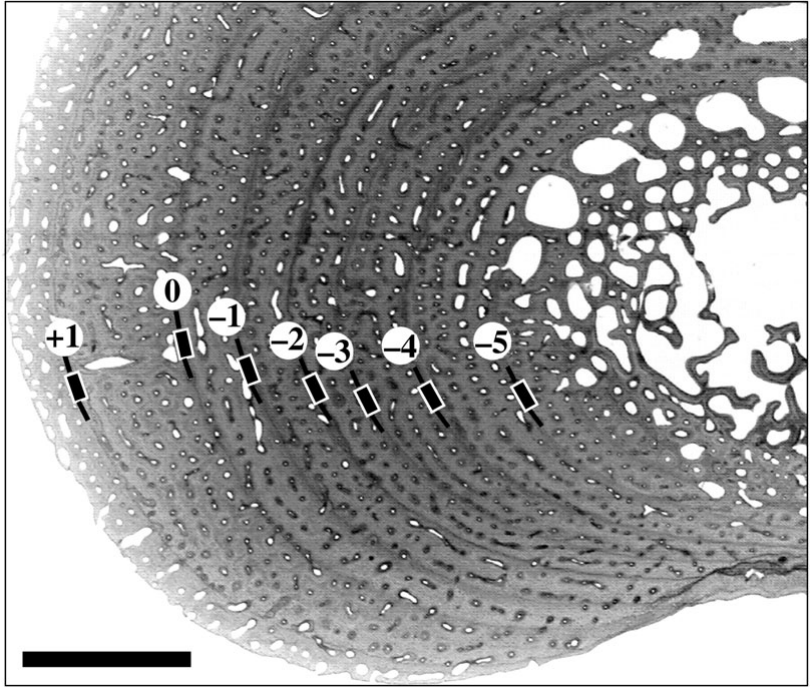

Fig. 2. Caretta caretta. Digital image of a partial cross-section of a loggerhead humerus at $10 \times$ magnification. Outer edge of bone is to the left of the image and the interior area of resorption is to the right. Black boxes and lines on the image highlight the most recent 5 lines of arrested growth (LAGs). 0 indicates LAG(0), which is the LAG prior to the shift in growth mark spacing. Scale bar $=1 \mathrm{~mm}$

LAGs interior to LAG(0) were labeled starting with -1 and counting inward to the bone medulla, and LAGs exterior to LAG(0) were numbered starting with 1 and counting out toward the periphery of the bone cortex (Fig. 2).

Using the methods presented by Snover et al. (2007), carapace lengths were estimated at each LAG as

$L_{i}=\left[L_{\mathrm{op}}+4.25\left(D_{i}-D_{\mathrm{op}}\right)^{0.85}\right]\left(L_{\mathrm{final}}\right)\left[L_{\mathrm{op}}+4.25\left(D_{\text {final }}-D_{\mathrm{op}}\right)^{0.85}\right]^{-1}$

where $L_{i}$ is carapace length $(\mathrm{cm})$ of the turtle at LAG $i$, $D_{i}$ is the diameter (mm) of LAG $i, L_{\text {op }}$ is the average carapace length $(\mathrm{cm})$ of loggerhead turtles at hatching, $D_{\text {op }}$ is the average diameter $(\mathrm{mm})$ of loggerhead humeri at hatching, $L_{\text {final }}$ is the final carapace length $(\mathrm{cm})$, and $D_{\text {final }}$ is the final humerus diameter $(\mathrm{mm})$. Snover et al. (2007) estimated $L_{\text {op }}$ at $4.6 \mathrm{~cm}$ and $D_{\text {op }}$ at $1.9 \mathrm{~mm}$ from measurements of hatchling loggerhead turtles from North Carolina, USA. Annual growth rate for year $i\left(\mathrm{~cm} \mathrm{SCL} \mathrm{yr}^{-1}\right)$ was then calculated as $L_{i}-L_{i-1}$. Mean SCL at LAG(0) estimates the average size at recruitment to the benthic habitat, which can be used to compare estimates of this size from other studies.

Stable isotope ratio analysis. In addition to the 23 loggerhead humeri, samples of Sargassum spp. and associated fauna from the Gulf Stream of coastal North Carolina, several species of nearshore benthic crabs typical of loggerhead diets (Wallace et al. 2009), samples of nearshore and vegetation, and stomach contents of freshly dead loggerheads were collected. 
These samples were frozen; muscle tissue was then isolated from the prey animals, and the plant samples were lyophilized for stable isotope ratio analysis (Knoff et al. 2002).

Using the stained thin sections as a guide, the location of the transitional LAG was easily identified on the untreated thin sections. Using sharp scissors, samples were taken exterior to the transitional LAG, then the LAG was cut away and samples were taken just interior to the transitional LAG. Prior to isotope analysis bone sections and prey and plant specimens were reflux-extracted with distilled dichloromethane to remove lipids. The bone samples and the prey and plant specimens were then ground to a fine powder into tin capsules for $\delta^{13} \mathrm{C}$ and $\delta^{15} \mathrm{~N}$ analysis.

The samples in the tin capsules were then converted to $\mathrm{CO}_{2}$ and $\mathrm{N}_{2}$ for isotope analysis using a Carlo Erba elemental analyzer which was coupled to an OPTIMA stable isotope ratio mass spectrometer (Micromass). This conversion takes place at a high combustion temperature involving strong oxidation $\left(1020^{\circ} \mathrm{C}\right)$, followed by reduction at a lower temperature $\left(650^{\circ} \mathrm{C}\right)$. The effluent gases are introduced into the mass spectrometer using a continuous flow interface. The stable isotope values are reported as follows:

$$
\delta^{\mathrm{N}} \mathrm{E}=\left[\left(R_{\text {sample }} / R_{\text {standard }}\right)-1\right] 10^{3}(\%)
$$

where $\mathrm{N}$ is the heavy isotope of element $\mathrm{E}$ and $R$ is the abundance ratio of the heavy to light isotopes $\left({ }^{13} \mathrm{C}:{ }^{12} \mathrm{C}\right.$ and ${ }^{15} \mathrm{~N}:{ }^{14} \mathrm{~N}$ ) of that element; thus if, for example, the isotope value of the sample is less than that of the standard, the value of the isotope in the sample is reported as a negative number reflecting a depletion in the heavy isotope relative to the standard. The standard for carbon is Peedee Belemnite (PDB) limestone, and for nitrogen the standard is atmospheric $\mathrm{N}_{2}$ (air), which are assigned $\delta^{\mathrm{N}} \mathrm{E}$ values of $0.0 \%$. The reproducibility of the measurement is typically better than $\pm 0.2 \%$ o for the elements using the continuous flow interface on the OPTIMA. The samples were measured against calibrated tanks of laboratory carbon dioxide and nitrogen gases. Materials of known composition were included approximately every tenth sample. Two-sample $t$-tests with unequal variances were performed on the stable isotope data from the bone sections to detect significant differences in $\delta^{13} \mathrm{C}$ values and $\delta^{15} \mathrm{~N}$ values before and after LAG(0).

\section{RESULTS}

\section{Growth mark analysis}

In all 23 bones, a consistent change was noted in the layering pattern of the growth marks. The LAGs became sequentially narrower from the interior of the

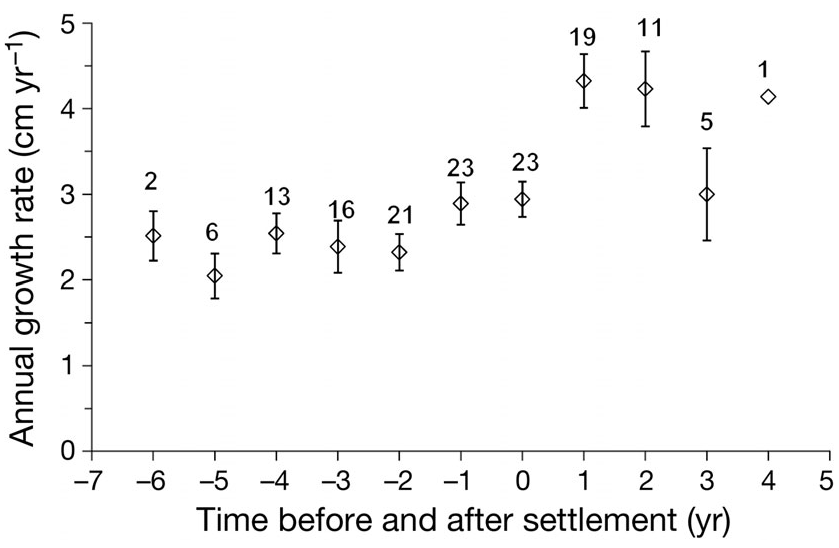

Fig. 3. Caretta caretta. Average annual growth in carapace length based on distance between growth marks in histological preparations of humeri. Bars indicate standard error; numbers indicate sample size for each year. Time 0 represents settlement to the benthic habitat and equates to the number assigned to the line of arrested growth (LAG). Negative values for time indicate that the turtle was in the pelagic at the time the growth mark was deposited. Time 0 growth rate is significantly lower than Time $1(\mathrm{p}<0.005)$

bone towards the exterior, until a point where they transitioned suddenly to being more widely spaced before gradually narrowing again (e.g. Fig. 2).

Diameters of the LAGs were converted to estimates of carapace length using Eq. (2), allowing for the estimation of annual growth rates $\left(\mathrm{cm} \mathrm{yr}^{-1}\right)$. The average growth rates earlier than and interior to LAG(0) were significantly lower than the average growth rates after LAG(0) (Student's t-test; p < 0.005; Fig. 3). Growth rates at $\mathrm{LAG}(0)$ were also significantly lower than the average growth rate at LAG(1) (Student's $t$-test; $\mathrm{p}<$ 0.005; Fig. 3). The average carapace length at LAG(0) was $45.5 \mathrm{~cm}$ SCL $(\mathrm{N}=23 ; 95 \% \mathrm{CI}=43.6-47.4 \mathrm{~cm} \mathrm{SCL})$. Carapace lengths back calculated from LAGs prior to LAG(0) ranged from 26.6 to $51.3 \mathrm{~cm}$ SCL.

\section{Stable isotope ratio analyses}

The average stable isotope content for both carbon and nitrogen was significantly different (2-sample $t$-tests with unequal variances) between the bone sampled internal to LAG(0) and external to it ( $p<0.005$, Fig. 4). For each bone, the $\delta^{13} \mathrm{C}$ values were more negative interior to LAG(0) than exterior to it, with a mean difference of $1.4 \%$. Also, the $\delta^{15} \mathrm{~N}$ values of each bone were lower interior to LAG(0), with a mean difference of $3.0 \%$.

Sargassum spp. and Spartina spp. vegetation had very similar $\delta^{15} \mathrm{~N}$ values, but Spartina spp. had a less negative $\delta^{13} \mathrm{C}$ value (Table 1 ). There was no overlap in $\delta^{15} \mathrm{~N}$ values between the pelagic and benthic fauna, 


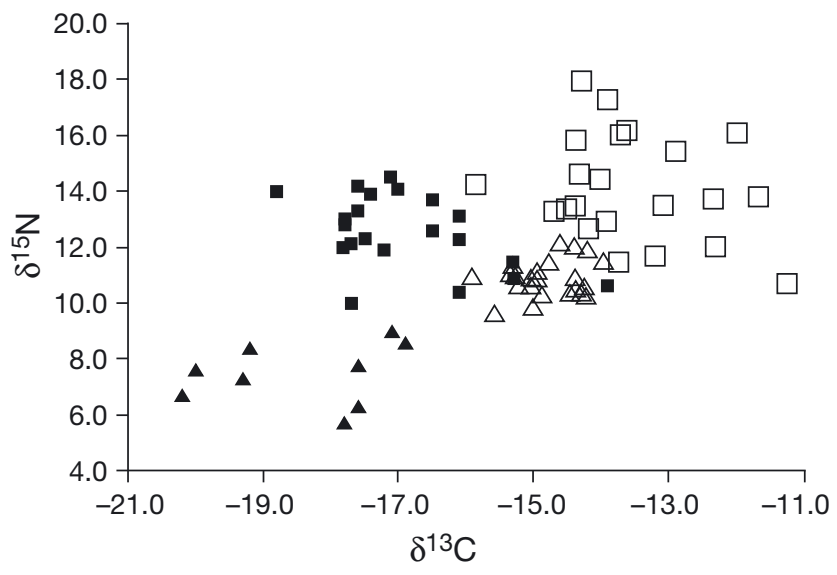

Fig. 4. Caretta caretta. Stable isotopes from the bones of loggerhead sea turtles. $\square$ : samples taken from after LAG(0), the line of arrested growth prior to the shift in growth mark spacing; $\Delta$ : samples taken between LAG( $(-1)$ and LAG $(0)$. a: stable isotope values for prey items sampled from the nearshore benthos; $\mathbf{~ : ~ s a m p l e s ~ t a k e n ~ f r o m ~ p r e y ~ i t e m s ~ f o u n d ~ i n ~ t h e ~}$ Sargassum community (see Table 1 for species)

Table 1. Stable isotopes of potential prey items of loggerhead sea turtles. If more than 1 specimen was analyzed, the sample size is given in parentheses next to the species name. Range and mean $( \pm \mathrm{SD})$ are reported

\begin{tabular}{|c|c|c|}
\hline Species & $\delta^{15} \mathrm{~N}$ & $\delta^{13} \mathrm{C}$ \\
\hline \multicolumn{3}{|l|}{ Nearshore benthos } \\
\hline Calinectes sapidus (7) & $\begin{array}{c}10 \text { to } 12.3 \\
(11.2 \pm 0.9)\end{array}$ & $\begin{array}{c}-17.8 \text { to }-13.9 \\
(-16.6 \pm 1.5)\end{array}$ \\
\hline Libinia dubia (5) & $\begin{array}{l}11.5 \text { to } 13.3 \\
(12.6 \pm 1.1)\end{array}$ & $\begin{array}{c}-18.8 \text { to }-15.3 \\
(-17.0 \pm 1.6)\end{array}$ \\
\hline Limulus polyphemus (9) & $\begin{array}{l}11.9 \text { to } 14.5 \\
(13.3 \pm 0.9)\end{array}$ & $\begin{array}{c}-17.8 \text { to }-16.1 \\
(-17.0 \pm 0.6)\end{array}$ \\
\hline Fish from stomach contents & 13.7 & -16.5 \\
\hline Spartina spp. & 3.9 & -12.8 \\
\hline Mean of fauna & $12.5 \pm 1.3$ & $-16.8 \pm 1.2$ \\
\hline \multicolumn{3}{|l|}{ Pelagic Sargassum associates } \\
\hline Lepas spp. & 7.6 & -20.0 \\
\hline Stomolophus meleagris & 8.4 & -19.2 \\
\hline Portunus sayi & 7.8 & -17.6 \\
\hline Planes minutes & 6.3 & -17.6 \\
\hline Scyllaea pelagica & 6.7 & -20.2 \\
\hline Monocanthus hispidus & 7.3 & -19.3 \\
\hline Leander tenuicorni (2) & $8.6,9$ & $-17.1,-16.9$ \\
\hline Leander seucorum & 5.7 & -17.8 \\
\hline Sargassum spp. & 4.3 & -17.2 \\
\hline Mean of fauna & $7.3 \pm 1.2$ & $-18.1 \pm 1.2$ \\
\hline
\end{tabular}

with the values for $\delta^{15} \mathrm{~N}$ being consistently higher among nearshore, benthic feeding animals compared to the animals associated with Sargassum spp. In general, the pelagic fauna had more negative $\delta^{13} \mathrm{C}$ values than the benthic fauna.

Stable isotope values in bone tissue were compared to values in potential prey items from each habitat
(Table 1, Fig. 4). The average $( \pm \mathrm{SD}) \delta^{15} \mathrm{~N}$ value for bone tissue internal to $\mathrm{LAG}(0)$ was $11.0 \pm 0.6 \%$ and for the animals associated with the Sargassum the average $\delta^{15} \mathrm{~N}$ value was $7.3 \pm 1.2 \%$. The average $\delta^{15} \mathrm{~N}$ for benthic invertebrates tested was $12.3 \pm 1.3 \%$ and for bone tissue external to $\operatorname{LAG}(0)$, the value was $14.1 \pm$ $1.9 \%$. The Sargassum animals had the lowest $\delta^{13} \mathrm{C}$ values $(-18.4 \pm 1.3 \%)$ followed by the benthic invertebrates $(-16.8 \pm 1.2 \%)$, the bone tissue interior to LAG(0) $(-14.8 \pm 0.5 \%)$ and the bone external to $\operatorname{LAG}(0)(-13.4 \pm 1.2 \%)$.

\section{DISCUSSION}

Stable isotopes indicate assimilation of food resources where modification of the isotope composition occurs as a function of trophic level, with $\delta^{15} \mathrm{~N}$ typically changing 3 to $4 \%$ per trophic level (Michener \& Schell 1994), although this can vary between different tissue types, with blood and blood plasma showing smaller differences (Seminoff et al. 2006). Taking this into account, our $\delta^{15} \mathrm{~N}$ values were consistent with loggerheads feeding in oceanic/pelagic habitats prior to LAG(0) and in neritic/benthic habitats after LAG(0). The values found in the current study are also similar to those found by McClellan et al. (2010) in red blood cells of loggerhead turtles from the same population. Values of $\delta^{13} \mathrm{C}$ are typically enriched by about $1 \%$ per trophic level (Michener \& Schell 1994; but see Seminoff et al. 2006). However, the differences between tissues vary (Tieszen et al. 1983, Hobson et al. 1996). The difference between diet and collagen in $\delta^{13} \mathrm{C}$ is typically about $+3.0 \%$ (Koch et al. 1994), which is the difference one would expect to find when comparing muscle from prey to the organic matter of sea turtle bones. Thus, the $\delta^{13} \mathrm{C}$ values also indicated that animals were feeding within a pelagic food web prior to LAG(0) and in a benthic food web after $\operatorname{LAG}(0)$. McClellan et al. (2010) did not find a significant difference in $\delta^{13} \mathrm{C}$ between red blood cells from oceanic and benthic loggerhead turtles from the same population as those in this study.

Organisms trade off high growth rates for decreased risks of mortality from predation early in their development, as documented for bluegill sunfish and Nassau grouper (Werner et al. 1983, Werner \& Hall 1988, Dahlgren \& Eggleston 2000). The pelagic zone of lakes is a much more profitable habitat for small bluegills than vegetated littoral zones, but small bluegills are confined to feeding in littoral zones when major predators, largemouth bass Micropterus salmoides, are present, trading off higher growth rates for decreased mortality until a size refuge is reached (Werner et al. 1983, Werner \& Hall 1988). Results from caging exper- 
iments demonstrate that small Nassau grouper, which typically use macroalgae habitats, have significantly higher growth rates but also significantly higher predation rates in the post-algal habitats used by larger grouper (Dahlgren \& Eggleston 2000). These sub-optimal habitats limit growth, and eventually an animal must shift to a more profitable habitat to reach reproductive size (Werner \& Gilliam 1984).

Based on the diameter of the growth marks, the size at which the shift occurred is consistent with what is known regarding the minimum size at which juvenile loggerheads are first observed in nearshore habitats of the southeastern USA (Bjorndal et al. 2000). The mean length at first settlement to the benthic habitat was estimated at $45.5 \mathrm{~cm}$ SCL. From a length frequency analysis, average size at settlement for the same population of loggerheads is estimated at $49 \mathrm{~cm}$ SCL $(53 \mathrm{~cm}$ CCL; Bjorndal et al. 2000). The agreement between the 2 values further supports the contention that the settlement mark was correctly identified in this population of loggerhead sea turtles and that the mark can be used to estimate age based on time since settlement.

The timing of ontogenetic shifts is critical to population dynamics, as together they determine life-cyclestage durations and time to reproductive maturity, as well as influencing size-specific growth and survivorship (Werner 1988). Population models developed for loggerheads from the southeastern USA use fixedstage durations for each of the major juvenile life stages, viz. pelagic and benthic (Crouse et al. 1987, Crowder et al. 1994, Heppell et al. 2003). Sources of mortality within the 2 juvenile habitats will likely vary, and it is important to understand the time that animals are exposed to both natural and anthropogenic mortality sources typical of the 2 habitats (Snover 2008). Data from individual turtles will provide the basis for more detailed stochastic or individual-based population models (DeAngelis \& Rose 1992).

Recent research by McClellan \& Read (2007) has demonstrated that some individuals captured in the benthos return to pelagic habitats. They found that $47 \%$ of the benthic loggerheads they tracked via satellite telemetry returned to pelagic habitats. As we sampled for stable isotopes immediately following LAG(0), it is possible that we would have missed isotope signatures typical of those animals that return to pelagic habitats after sampling the benthic habitat. Additional sampling of sequential growth layers after the transition would corroborate the findings of McClellan \& Read (2007) and provide valuable detailed information, in a more cost-efficient manner, on the variability in habitat use and the factors that may influence this variability, including climate change and variable sea surface temperatures, for this cryptic and difficult to study species (Snover 2008).
Numerous studies have used stable isotopes to demonstrate habitat changes through time using feathers, hair, teeth, and carapace tissue (Hobson \& Sease 1998, Burton \& Koch 1999, Walker \& Macko 1999, Walker et al. 1999, Cerling et al. 2006, Estrada et al. 2006, West et al. 2006, Reich et al. 2007, Knoff et al. 2008, Newsome et al. 2009). By cross-validating the technique with skeletochronology, it is clear that the growth rate shift occurs in conjunction with habitat shifts. The growth rates prior to LAG(0) are representative of pelagic growth rates and hence offer a wealth of information about a life history stage that has been nearly impossible to access. The combination of skeletochronology and stable isotopes provides a viable method for assessing growth rates, diet, and habitat ontogeny in sea turtles.

Acknowledgements. Most of the humeri were received through the Sea Turtle Stranding and Salvage Network, a cooperative endeavor between the National Marine Fisheries Service (NMFS), other federal and state agencies, many academic and private entities, and innumerable volunteers. Special thanks to R. Boettcher and W. Teas. Funding was provided by the NMFS, SEFSC, and the Office of Protected Resources. All work was done under, and complied with, the provisions of Sea Turtle Research Permit TE-676379-2 issued by the US Fish and Wildlife Service.

\section{LITERATURE CITED}

Bjorndal KA, Bolten AB, Martins HR (2000) Somatic growth model of juvenile loggerhead sea turtles Caretta caretta: duration of pelagic stage. Mar Ecol Prog Ser 202:265-272

Bjorndal KA, Bolten AB, Dellinger T, Delgado C, Martins HR (2003) Compensatory growth in oceanic loggerhead sea turtles: response to a stochastic environment. Ecology 84:1237-1249

Bolten AB, Bjorndal KA, Martins HR, Dellinger T, Boscoito MJ, Encalada SE, Bowen BW (1998) Transatlantic developmental migrations of loggerhead sea turtles demonstrated by mtDNA sequence analysis. Ecol Appl 8:1-7

> Burton RK, Koch PL (1999) Isotope tracking of foraging and long-distance migration in northeastern Pacific pinnipeds. Oecologia 119:578-585

Carr A (1987) New perspectives on the pelagic stage of sea turtle development. Conserv Biol 1:103-121

Castanet J, Francillon-Viellot H, Meunier FJ, De Ricqles A (1993) Bone and individual aging. In: Hall BK (ed) Bone, Vol 7. Bone growth-B. CRC Press, Boca Raton, FL, p 245-283

Cerling TE, Wittemyer G, Rasmussen HB, Vollrath F, Cerling CE, Robinson TJ, Douglas-Hamilton I (2006) Stable isotopes in elephant hair document migration patterns and diet changes. Proc Natl Acad Sci USA 103:371-373

Coles WC, Musick JA, Williamson LA (2001) Skeletochronology validation from an adult loggerhead (Caretta caretta). Copeia 2001:240-242

Crouse DT, Crowder LB, Caswell H (1987) A stage-based population model for loggerhead sea turtles and implications for conservation. Ecology 68:1412-1423

Crowder LB, Crouse DT, Heppell SS, Martin TH (1994) Predicting the impact of turtle excluder devices on loggerhead sea turtle populations. Ecol Appl 4:437-445 
Dahlgren CP, Eggleston DB (2000) Ecological processes underlying ontogenetic habitat shifts in a coral reef fish. Ecology 81:2227-2240

DeAngelis DL, Rose KA (1992) Which individual-based approach is most appropriate for a given problem? In: DeAngelis DL, Gross LJ (eds) Individual-based models and approaches in ecology. Chapman \& Hall, New York, NY, p 67-87

Estrada JA, Rice AN, Natanson LJ, Skomal GB (2006) Use of isotope analyses of vertebrae in reconstructing ontogenetic feeding ecology in white sharks. Ecology 87:829-834

Etherington LL, Eggleston DB, Stockhausen WT (2003) Partitioning loss rates of early juvenile blue crabs from seagrass habitats into mortality and emigration. Bull Mar Sci 72:371-391

Heppell SS, Crowder LB, Crouse DT, Epperly SP, Frazer NB (2003) Population models for Atlantic loggerheads: past, present and future. In: Bolten A, Witherington B (eds) Loggerhead sea turtles. Smithsonian Books, Washington, DC, p 255-273

> Hobson KA, Sease JL (1998) Stable isotope analyses of tooth annuli reveal temporal dietary records: an example using Steller sea lions. Mar Mamm Sci 14:116-129

Hobson KA, Schell DM, Renouf D, Noseworthy E (1996) Stable carbon and nitrogen isotopic fractionation between diet and tissues of captive seals: implications for dietary reconstructions involving marine mammals. Can J Fish Aquat Sci 53:528-533

Kelly JF (2000) Stable isotopes of carbon and nitrogen in the study of avian and mammalian trophic ecology. Can J Zool 78:1-27

Klinger RC, Musick JA (1992) Annular growth layers in juvenile loggerhead turtles (Caretta caretta). Bull Mar Sci 51:224-230

Klinger RC, Musick JA (1995) Age and growth of loggerhead turtles (Caretta caretta) from Chesapeake Bay. Copeia 1995:204-209

Knoff AJ, Macko SA, Erwin RM, Brown KM (2002) Stable isotope analysis of temporal variation in the diets of prefledged laughing gulls. Waterbirds 25:142-148

Knoff A, Hohn A, Macko S (2008) Ontogenetic diet changes in bottlenose dolphins (Tursiops truncatus) reflected through stable isotopes. Mar Mamm Sci 24:128-137

Koch PL, Fogel ML, Tuross N (1994) Tracing the diets of fossil animals using stable isotopes. In: Lajtha $\mathrm{K}$, Michener $\mathrm{RH}$ (eds) Stable isotopes in ecology and environmental science. Blackwell, Boston, MA, p 63-92

- McClellan CM, Read AJ (2007) Complexity and variation in loggerhead sea turtle life history. Biol Lett 3:592-594

McClellan CM, Braun-McNeill J, Avens L, Wallace BP, Read AJ (2010) Stable isotopes confirm a foraging dichotomy in juvenile loggerhead sea turtles. J Exp Mar Biol Ecol 387:44-51

Michener RH, Schell DM (1994) Stable isotope ratios as tracers in marine aquatic food webs. In: Lajtha $\mathrm{K}$, Michener $\mathrm{RH}$ (eds) Stable isotopes in ecology and environmental sciences. Blackwell, Boston, MA, p 138-157

- Minagawa M, Wada E (1984) Stepwise enrichment of ${ }^{15} \mathrm{~N}$ along food chains: further evidence and the relation between $\delta^{15} \mathrm{~N}$ and animal age. Geochim Cosmochim Acta 48:1135-1140

Newsome SD, Etnier MA, Monson DH, Fogel ML (2009) Retrospective characterization of ontogenetic shifts in killer whale diets via $\delta^{13} \mathrm{C}$ and $\delta^{15} \mathrm{~N}$ analysis of teeth. Mar Ecol Prog Ser 374:229-242

Editorial responsibility: Brendan Godley, University of Exeter, Cornwall Campus, UK
Parham JF, Zug GR (1997) Age and growth of loggerhead sea turtles (Caretta caretta) of coastal Georgia: an assessment of skeletochronological age-estimates. Bull Mar Sci 61: 287-304

Rau GH, Ainley DG, Bengtson JL, Torres JJ, Hopkins TL (1992) ${ }^{15} \mathrm{~N} /{ }^{14} \mathrm{~N}$ and ${ }^{13} \mathrm{C} /{ }^{12} \mathrm{C}$ in Weddell Sea birds, seals, and fish: implications for diet and trophic structure. Mar Ecol Prog Ser 84:1-8

Reich KJ, Bjorndal KA, Bolten AB (2007) The 'lost years' of green turtles: using stable isotopes to study cryptic life stages. Biol Lett 3:712-714

Seminoff JA, Jones TT, Eguchi T, Jones DR, Dutton PH (2006) Stable isotope discrimination $\left(\delta^{13} \mathrm{C}\right.$ and $\left.\delta^{15} \mathrm{~N}\right)$ between soft tissues of the green sea turtle Chelonia mydas and its diet. Mar Ecol Prog Ser 308:271-278

Shafer DJ (2000) Evaluation of periodic and aperiodic otolith structures and somatic-otolith scaling for use in retrospective life history analysis of a tropical marine goby, Bathygobius coalitus. Mar Ecol Prog Ser 199:217-229

Snover ML (2008) Ontogenetic habitat shifts in marine organisms: influencing factors and the impact of climate variability. Bull Mar Sci 83:53-67

Snover ML, Hohn AA (2004) Validation and interpretation of annual skeletal marks in loggerhead (Caretta caretta) and Kemp's ridley (Lepidochelys kempii) sea turtles. Fish Bull 102:682-692

Snover ML, Avens L, Hohn AA (2007) Back-calculating length from skeletal growth marks in loggerhead sea turtles Caretta caretta. Endang Species Res 3:95-104

Tieszen LL, Boutton TW, Tesdahl KG, Slade NA (1983) Fractionation and turnover of stable carbon isotopes in animal tissues: implications for $\delta^{13} \mathrm{C}$ analysis of diet. Oecologia 57:32-37

- Walker JL, Macko SA (1999) Dietary studies of marine mammals using stable carbon and nitrogen isotopic ratios of teeth. Mar Mamm Sci 15:314-334

- Walker JL, Potter CW, Macko SA (1999) The diets of modern and historic bottlenose dolphin populations reflected through stable isotopes. Mar Mamm Sci 15:335-350

Wallace BP, Avens L, Braun-McNeill J, McClellan CM (2009) The diet composition of immature loggerheads: insights on trophic niche, growth rates and fisheries interactions. J Exp Mar Biol Ecol 373:50-57

Werner EE (1988) Size, scaling, and the evolution of complex life cycles. In: Ebenman B, Persson L (eds) Size-structured populations. Springer-Verlag, Berlin, p 60-81

> Werner EE, Gilliam JF (1984) The ontogenetic niche and species interactions in size-structured populations. Annu Rev Ecol Syst 15:393-425

Werner EE, Hall DJ (1988) Ontogenetic habitat shifts in bluegill: the foraging rate-predation risk trade-off. Ecology 69:1352-1366

> Werner EE, Gilliam JF, Hall DJ, Mittelbach GG (1983) An experimental test of the effects of predation risk on habitat use in fish. Ecology 64:1540-1548

West JB, Bowen GB, Cerling TE, Ehleringer JR (2006) Stable isotopes as one of nature's ecological recorders. Trends Ecol Evol 21:408-414

Zug GR, Wynn AH, Ruckdeschel C (1986) Age determination of loggerhead sea turtles, Caretta caretta, by incremental growth marks in the skeleton. Smithson Contrib Zool 427:1-34

Zug GR, Balazs GH, Wetherall JA (1995) Growth in juvenile loggerhead seaturtles (Caretta caretta) in the north Pacific pelagic habitat. Copeia 1995:484-487

Submitted: January 5, 2010; Accepted: September 3, 2010

Proofs received from author(s): November 6, 2010 